\title{
A Poesia Urbana de Chico Buarque
}

\section{Vivian C. Alves de Carvalho*}

Resumo: O presente ensaio trata da visão de Chico Buarque sobre a sociedade urbana brasileira expressa em suas canções. Observa-se uma mudança de ponto de vista ao longo do tempo, acompanhando o crescimento das cidades e também de seus flagelos. Nos anos 60 , temos um artista consciente dos problemas, mas otimista com relação ao futuro. Nos anos 70, temos a expressão da falta de esperança diante do horror da ditadura militar. A partir da década de 90, tempos de democracia, Chico assume seu amor pelo Rio de Janeiro - num primeiro momento, enaltecendo suas belezas, e depois, reconhecendo seus problemas.
Abstract: The present paper focuses on Chico Buarque's view concerning the urban Brazilian society expressed in his songs. There is a change in his point of view throughout the years following the growth of the big cities and their scourges. In the 60's, we have an artist who is aware of the problems, but is optimistic about the future. In the 70's, we have a total hopelessness in face of the military dictatorship horror. From the 90's on, democracy times, Chico assumes his love for Rio de Janeiro - firstly, praising its beauty, and then recognizing its problems.

Palavras-chave: Chico Buarque; cidade grande; sociedade brasileira.

Keywords: Chico Buarque; big city; Brazilian society.

\section{Primeira parte}

Entre os muitos temas abordados por Chico Buarque em sua obra poética destaca-se a cidade, ou seja, o espaço, a vida urbana e todos os seus elementos. Porém, o sentimento expresso não é sempre o mesmo. Há uma variação de tom. Entre Pedro Pedreiro, uma de suas primeiras canções, lançada em 1965, e Subúrbio, do álbum mais recente, lançado em 2006, sabemos que a caminhada foi longa e que sua visão sobre a sociedade brasileira foi se moldando aos poucos, foi amadurecendo a cada novo disco. A visão nostálgica apresentada em A Banda contrasta radicalmente com a acidez de Construção, e há uma diferença de apenas cinco anos entre elas, sendo a primeira de 1966 e a segunda de 1971. Entretanto, apesar dos contrastes, é possível notar uma definição de ponto de vista: malandros, pivetes, guris, entre tantas outras figuras tipicamente urbanas, povoam a obra do autor, evidenciando a preocupação com o destino da sociedade

\footnotetext{
${ }^{*}$ Mestranda
} 
brasileira. Esse Chico Buarque militante das décadas de 70 e 80 chega aos anos 90 aparentemente conformado com a miséria das cidades grandes em geral e se volta para o Rio de Janeiro, o seu Rio de Janeiro, tão bem desenhado na canção Carioca, que está no álbum intitulado As cidades, de 1998. Em 2006, a já citada Subúrbio, de Carioca, mostra um retorno do olhar do poeta para os marginalizados, mas de um jeito completamente diferente, com uma leveza que parece não combinar com aquilo que descreve.

É interessante também o fato de que, na década de 90, o poeta dá lugar também ao romancista. Estorvo, de 1991 e Benjamim, de 1995 são narrativas urbanas e desconcertantes que, cada uma à sua maneira, contribuem para o retrato não muito iluminado da sociedade atual pintado por Chico Buarque. Em 2002, o estrondoso sucesso Budapeste confirma a maestria do autor no campo da literatura e mostra mais um ou alguns lados negativos da vida nas cidades grandes.

A proposta deste ensaio é analisar as diversas perspectivas do poeta Chico Buarque em relação à cidade, à vida urbana e seus flagelos. É importante esclarecer que, embora esteja lidando com canções, que a rigor não são poemas, optei por não me deter nos aspectos musicais, como melodia, harmonia, arranjos, para focalizar apenas a temática. Dessa forma, as letras são aqui tratadas em seu aspecto poético, lírico. Não me deterei, também, nos romances. Acredito que poderiam ajudar a montar o quadro da sociedade urbana do Brasil, entretanto, a idéia deste trabalho é estudar apenas a poesia do autor. Além disso, o tamanho de um ensaio não comportaria mais esse estudo, que certamente não seria breve. Contudo, não descarto a possibilidade de estendê-lo futuramente. Por ora, fiquemos com as canções.

\section{Segunda parte}

O primeiro disco de Chico Buarque abre com A Banda:

Estava à toa na vida

O meu amor me chamou

Pra ver a banda passar

Cantando coisas de amor

A minha gente sofrida

Despediu-se da dor

Pra ver a banda passar

Cantando coisas de amor

O homem sério que contava dinheiro parou

$\mathrm{O}$ faroleiro que contava vantagem parou

A namorada que contava as estrelas parou

Para ver, ouvir e dar passagem

A moça triste que vivia calada sorriu

A rosa triste que vivia fechada se abriu

E a meninada toda se assanhou

Pra ver a banda passar

Cantando coisas de amor 
O velho fraco se esqueceu do cansaço e pensou

Que ainda era moço pra sair no terraço e

dançou

A moça feia debruçou na janela

Pensando que a banda tocava pra ela

A marcha alegre se espalhou na avenida e insistiu

A lua cheia que vivia escondida surgiu

Minha cidade toda se enfeitou
Pra ver a banda passar cantando coisas de amor

Mas para meu desencanto

O que era doce acabou

Tudo tomou seu lugar

Depois que a banda passou

E cada qual no seu canto

Em cada canto uma dor

Depois da banda passar

Cantando coisas de amor

Trata-se de um episódio, um breve momento em que uma cidade pára para ver e ouvir uma banda cantando coisas de amor. Personagens diversos aparecem, com seus respectivos problemas, que são esquecidos até que chegue ao fim a passagem da tal banda.

Por trás dessa aparente simplicidade, encontramos versos que parecem traduzir o sentimento de solidão que é tema de poesia há décadas: E cada qual no seu canto / Em cada canto uma dor. $\mathrm{O}$ individualismo é a marca maior da modernidade. Cada um cuida da sua vida, das suas angústias, dos seus problemas. Não há tempo para olhar para o lado, estender a mão a algum necessitado. A Banda nos mostra que nem tudo está perdido. A simples passagem de uma banda de música é capaz de fazer uma cidade inteira parar, esquecer seus problemas e ser feliz, ainda que por um brevíssimo período. Por mais que isso possa parecer muito pessimista, creio que é justamente o contrário. Ao mesmo tempo em que notamos uma nostalgia em relação ao passado, podemos também perceber a esperança de que alguma coisa pode nos salvar. E a banda seria um símbolo disso: de algo que vai nos fazer parar e prestar mais atenção às coisas boas e belas da vida.

Maria Rita Kehl (2006), em matéria publicada na revista Bravo! afirma:

Por obra da ironia que marca o vínculo inconsciente entre a obra de arte e o gosto do público, $A$ Banda estourou na cidade que mais crescia no Brasil ao dar voz à memória interiorana do país recém-urbanizado. A rua onde o poeta estava à toa quando a banda passou "cantando coisas de amor", espaço de convivência pacífica e plural, já fazia parte da memória recalcada pelo "Brasil Grande" do projeto militar. (KEHL, 2006, p. 75)

Kehl levanta uma questão interessante: $A$ Banda, que à primeira vista não se enquadraria no que estamos chamando de poesia urbana, representa, de certo modo, uma contradição. Na década de 1960 o Brasil está em plena ditadura militar, mas também em pleno desenvolvimento econômico e industrial. Está lutando com todas as forças para assumir um caráter urbano, quando surge um artista cantando a beleza de um passado pacífico e nada urbano. E, apesar da dissonância entre o poema e a realidade, $A$ Banda faz um enorme sucesso e consagra o jovem 
Chico Buarque como grande compositor. Portanto, podemos afirmar sem medo de errar que não é só aos poetas que a angústia da modernidade aflige.

No mesmo disco, cinco faixas adiante, encontramos Pedro Pedreiro:

Pedro pedreiro penseiro esperando o trem Manhã, parece, carece de esperar também Para o bem de quem tem bem

De quem não tem vintém

Pedro pedreiro fica assim pensando

Assim pensando o tempo passa

E a gente vai ficando pra trás

Esperando, esperando, esperando

Esperando o sol

Esperando o trem

Esperando o aumento

Desde o ano passado

Para o mês que vem

Pedro pedreiro penseiro esperando o trem Manhã, parece, carece de esperar também Para o bem de quem tem bem

De quem não tem vintém

Pedro pedreiro espera o carnaval

E a sorte grande no bilhete pela federal

Todo mês

Esperando, esperando, esperando

Esperando o sol

Esperando o trem

Esperando aumento

Para o mês que vem

Esperando a festa

Esperando a sorte

E a mulher de Pedro

Está esperando um filho

Pra esperar também
Pedro pedreiro penseiro esperando o trem Manhã, parece, carece de esperar também Para o bem de quem tem bem

De quem não tem vintém

Pedro pedreiro está esperando a morte Ou esperando o dia de voltar pro norte Pedro não sabe mas talvez no fundo Espera alguma coisa mais linda que o mundo

Maior do que o mar

Mas pra que sonhar

Se dá o desespero de esperar demais Pedro pedreiro quer voltar atrás Quer ser pedreiro pobre e nada mais Sem ficar esperando, esperando, esperando Esperando o sol

Esperando o trem

Esperando aumento para o mês que vem Esperando um filho pra esperar também Esperando a festa

Esperando a sorte

Esperando a morte

Esperando o norte

Esperando o dia de esperar ninguém Esperando enfim nada mais além Da esperança aflita, bendita, infinita Do apito do trem

Pedro pedreiro pedreiro esperando Pedro pedreiro pedreiro esperando Pedro pedreiro pedreiro esperando o trem Que já vem, que já vem, que já vem...

A situação aqui é bastante diferente da anterior. Trata-se de um sujeito que veio do norte para tentar melhorar de vida numa cidade grande, urbanizada. O máximo que consegue é um emprego de pedreiro, mas isso não lhe tira a esperança. A palavra que mais aparece nos versos de Pedro Pedreiro é "esperando". Pedro espera o trem, espera o aumento, espera o carnaval, espera ganhar na loteria. Sua mulher espera mais um filho, e Pedro, no fundo, sabe que o destino do menino é, também, esperar.

Logo após dar-se conta de que mais um ser humano está vindo ao mundo para ele sustentar, Pedro passa a esperar coisas diferentes: o dia de voltar para a sua terra, a morte. Chega a sonhar com algo maior - Pedro não sabe mas talvez no fundo / Espera alguma coisa mais linda 
que o mundo / maior do que o mar - porém a realidade não tarda a lhe trazer de volta - Mas pra que sonhar / Se dá um desespero de esperar demais / Pedro pedreiro quer voltar atrás / Quer ser pedreiro pobre e nada mais.

Assim, notamos uma certa confusão quanto ao objeto da esperança do pobre pedreiro, porém, é uma esperança que nunca o abandona. Por mais que às vezes ele deseje a morte, ele sabe que precisa continuar trabalhando. Ainda que cogite voltar para sua terra natal, Pedro sabe que lá definitivamente não há esperança de um futuro melhor. E assim ele vai ficando na cidade, esperando o trem que já vem, que já vem, que já vem...

Alguns anos depois, com Construção, notamos que o trem que Pedro Pedreiro esperava não chegou:

Amou daquela vez como se fosse a última Beijou sua mulher como se fosse a última E cada filho seu como se fosse o único E atravessou a rua com seu passo tímido Subiu a construção como se fosse máquina Ergueu no patamar quatro paredes sólidas Tijolo com tijolo num desenho mágico Seus olhos embotados de cimento e lágrima Sentou pra descansar como se fosse sábado Comeu feijão com arroz como se fosse um príncipe

Bebeu e soluçou como se fosse um náufrago Dançou e gargalhou como se ouvisse música E tropeçou no céu como se fosse um bêbado E flutuou no ar como se fosse um pássaro

E se acabou no chão feito um pacote flácido Agonizou no meio do passeio público Morreu na contramão atrapalhando o tráfego

Amou daquela vez como se fosse o último Beijou sua mulher como se fosse a única E cada filho como se fosse o pródigo
E atravessou a rua com seu passo bêbado Subiu a construção como se fosse sólido Ergueu no patamar quatro paredes mágicas Tijolo com tijolo num desenho lógico Seus olhos embotados de cimento e tráfego Sentou pra descansar como se fosse um príncipe Comeu feijão com arroz como se fosse o máximo Bebeu e soluçou como se fosse máquina Dançou e gargalhou como se fosse o próximo E tropeçou no céu como se ouvisse música E flutuou no ar como se fosse sábado E se acabou no chão feito um pacote tímido Agonizou no meio do passeio náufrago Morreu na contramão atrapalhando o público

Amou daquela vez como se fosse máquina Beijou sua mulher como se fosse lógico Ergueu no patamar quatro paredes flácidas Sentou pra descansar como se fosse um pássaro E flutuou no ar como se fosse um príncipe E se acabou no chão feito um pacote bêbado Morreu na contra-mão atrapalhando o sábado

É claro que não há nada que confirme explicitamente a ligação entre Pedro Pedreiro e o operário de Construção. Entretanto, pelo menos em termos interpretativos, é perfeitamente lícito considerar esta como uma espécie de continuação daquela. É bastante verossímil imaginar um sujeito que vem do norte para a cidade grande tentar a sorte, se depara com uma dura realidade, arruma um emprego que é o máximo que sua qualificação pode lhe proporcionar e disso não consegue passar. A esperança de Pedro Pedreiro não é suficiente, e acaba sendo substituída por 
uma angústia profunda, por uma depressão que o leva a cometer um ato extremo, como podemos ler no poema descrito acima.

Tudo acontece gradativamente, vamos nos dando conta do que está por vir aos poucos. O dia corre normalmente, como na sua rotina diária. A diferença é que agora ele se despede da mulher e dos filhos como se não os fosse ver novamente; trabalha, levanta paredes, com lágrimas nos olhos, come seu almoço soluçando, entra num estado de delírio - Dançou e gargalhou como se ouvisse música - e põe fim à própria vida. A marginalização não o abandona nem na hora de sua morte, uma vez que ele morre atrapalhando o tráfego.

A história está contada na primeira estrofe. É uma angústia que vai aumentando a cada verso, até chegar ao trágico fim. As duas estrofes seguintes são constituídas de variações dos versos já colocados na primeira, não deixando dúvidas sobre o infortúnio do pobre homem. A repetição das frases contribui para tornar a situação ainda mais dolorosa e as proparoxítonas que invariavelmente encerram cada um dos versos de alguma forma simbolizam a rigidez da cidade grande.

Os elementos urbanos se misturam aos frutos do momento de aflição, emoção e delírio do operário: os tijolos formando um desenho mágico, que se tornam paredes mágicas depois, os olhos embotados de cimento e lágrima, o pacote flácido flutuando sobre o asfalto. Dessa forma, fica clara a relação entre o suicídio e a dificuldade e a dureza da vida urbana.

\section{Terceira parte}

Outra faceta da cidade bastante explorada por Chico é a malandragem. De um lado temos aquele malandro "pratica a astúcia pela astúcia", usando os termos de Antonio Candido em Dialética da Malandragem, para se safar de confusões cotidianas, como pagar a conta do bar; o clássico malandro carioca tão presente nos sambas de Noel Rosa, por exemplo. De outro lado, o malandro profissional, com gravata e capital, que nunca se dá mal.

Comecemos com a canção que introduz a Ópera do Malandro, peça escrita por Chico Buarque em 1978, O malandro:

$\mathrm{O}$ malandro/Na dureza

Senta à mesa/Do café

Bebe um gole/De cachaça

Acha graça/E dá no pé
O garçom/No prejuízo

Sem sorriso/Sem freguês

De passagem/Pela caixa

Dá uma baixa/No português 


\begin{tabular}{|c|c|}
\hline O galego/Acha estranho & Rejeitada/No barril \\
\hline Que o seu ganho/Tá um horror & O alambique/Tem chilique \\
\hline Pega o lápis/Soma os canos & Contra o Banco/Do Brasil \\
\hline \multicolumn{2}{|l|}{ Passa os danos/Pro distribuidor } \\
\hline Mas o frete/Vê que ao todo & Com orgulho/De produtor \\
\hline Há engodo/Nos papéis & Mas a sua/Raiva cega \\
\hline E pra cima/Do alambique & Descarrega/No carregador \\
\hline \multicolumn{2}{|l|}{ Dá um trambique/De cem mil réis } \\
\hline O usineiro/Nessa luta & Este chega/Pro galego \\
\hline Grita (ponte que partiu) & Nega arreglo/Cobra mais \\
\hline Não é idiota/Trunca a nota & A cachaça/Tá de graça \\
\hline Lesa o Banco/Do Brasil & Mas o frete/Como é que faz? \\
\hline Nosso banco/Tá cotado & O galego/Tá apertado \\
\hline No mercado/Exterior & Pro seu lado/Não tá bom \\
\hline Então taxa/A cachaça & Então deixa/Congelada \\
\hline A um preço/Assustador & A mesada/Do garçom \\
\hline Mas os ianques/Com seus tanques & O garçom vê/Um malandro \\
\hline Têm bem mais o/Que fazer & Sai gritando/Pega ladrão \\
\hline E proíbem/Os soldados & E o malandro/Autuado \\
\hline Aliados/De beber & É julgado e condenado culpado \\
\hline & Pela situação \\
\hline
\end{tabular}

A cachaça/Tá parada

O malandro, de acordo com a concepção de Antonio Candido em Dialética da Malandragem, ensaio dedicado ao romance Memórias de um Sargento de Milícias, de Manuel Antônio de Almeida, é aquele sujeito que oscila entre o pólo da ordem e o pólo da desordem. Ou seja, se comporta ora "segundo as normas estabelecidas", ora "em oposição ou pelo menos em integração duvidosa em relação a elas" (CANDIDO, 2004, p. 32), optando por agir de uma forma ou de outra conforme a conveniência: se lhe convém sair do bar sem pagar a conta, não é porque isso representa uma violação das regras estabelecidas que vai deixar de fazê-lo. Se lhe convier infringir as leis, o fará sem culpa. Mas se não houver motivo para tanto, evitará a desonestidade. De forma resumida, essa é uma boa definição do típico malandro carioca.

Os versos acima transcritos representam uma espécie de efeito dominó, uma vez que um personagem vai prejudicando o outro em nome dos próprios interesses sucessivamente. Assim, todos acabam entrando no pólo da desordem de forma circular. O malandro dá início à história: bebe um gole de cachaça e sai sem pagar; o garçom se dá conta de que sairá no prejuízo e rouba um dinheiro do caixa do bar; o dono do bar, o português, estranha o rombo nas finanças e dá um calote no distribuidor; este por sua vez passa a perna no usineiro, que passa a dever para o banco; assim, mais impostos são cobrados sobre a cachaça; os ianques, então, proíbem os soldados de beber e a cachaça fica parada no barril. Como estamos falando de um círculo, a situação passa a 
atingir novamente os personagens iniciais: o usineiro descarrega no distribuidor, que cobra do português, que corta o salário do garçom, que, finalmente, trata de entregar o malandro à justiça.

Portanto, temos aqui um tipo de malandragem que tem suas consequiências, mas que não chegam a causar um dano irreparável à sociedade como um todo. É uma malandragem que, no fim das contas, tem um efeito mais negativo para o próprio malandro do que para aqueles que ele consegue burlar. De qualquer forma, nota-se que a malandragem está em todos os personagens, nenhum deles hesita em prejudicar o próximo para livrar a própria cara. Sendo assim, ladrão que rouba ladrão tem cem anos de perdão; não há razão para sentimento de culpa ou arrependimento. O malandro foi o único que foi parar na justiça porque foi o causador de tudo, não porque representa o maior perigo para a sociedade. Além disso, o malandro não tem a quem recorrer.

Mas Chico Buarque enxerga um outro tipo de malandro que é bem mais perigoso. Oscila entre os pólos da ordem e da desordem de uma maneira diferente: aparentemente é um cidadão de bem, que respeita as regras e luta pelo povo; mas na realidade está apenas cuidando de interesses pessoais. Dizendo de outro modo, na verdade esse malandro não conhece de fato a ordem, pois só está nela nas aparências. Vejamos o seguinte poema:

Eu fui fazer um samba em homenagem
À nata da malandragem
Que conheço de outros carnavais
Eu fui à Lapa e perdi a viagem
Que aquela tal malandragem
Não existe mais
Agora já não é normal
O que dá de malandro regular, profissional
Malandro com aparato de malandro oficial
Malandro candidato a malandro federal

Eu fui fazer um samba em homenagem À nata da malandragem

Eu fui à Lapa e perdi a viagem

Que aquela tal malandragem

Agora já não é normal

Malandro com aparato de malandro oficial

O que podemos observar é um poeta ciente de que aquela malandragem quase ingênua de antigamente, da "astúcia pela astúcia" simplesmente não existe mais. O que temos hoje é o malandro poderoso, que por mais que todos reconheçam seus atos ilícitos, jamais sofre as consequiências deles. Esta canção é também faz parte da Ópera do Malandro, de 1978. Há quase trinta anos atrás, Chico Buarque parecia prever o que se tornaria o vergonhoso cenário político nacional: Malandro candidato a malandro federal / Malandro com contrato, com gravata e capital / Que nunca se dá mal.

\author{
Malandro com retrato na coluna social \\ Mas o malandro pra valer \\ - não espalha \\ Aposentou a navalha \\ Dizem as más línguas que ele até trabalha \\ Mora lá longe e chacoalha \\ Num trem da Central
}


Aquele malandro dos velhos tempos foi obrigado a se render às exigências da dura realidade das grandes cidades: trabalhar muito para sustentar mulher e filho e tralha e tal. Enquanto o novo malandro se ocupa em sair em colunas sociais, ele chacoalha num trem da Central. Assim, fica constatado: Que aquela tal malandragem / Não existe mais.

\section{Quarta parte}

Uma grave conseqüência do acelerado avanço da urbanização e do descaso político é a desigualdade social. E essa questão não passou despercebida pelos olhos do poeta Chico Buarque. São inúmeras as canções que abordaram o tem. Eis aqui Brejo da Cruz, que é exemplar:

$\begin{array}{ll}\begin{array}{l}\text { A novidade } \\ \text { Que tem no Brejo da Cruz }\end{array} & \begin{array}{l}\text { Mas há milhões desses seres } \\ \text { Que se disfarçam tão bem } \\ \text { Eue ninguém pergunta }\end{array} \\ \begin{array}{l}\text { Se alimentar de luz } \\ \text { Alucinados }\end{array} & \text { De onde essa gente vem } \\ \text { Meninos ficando azuis } & \text { São jardineiros } \\ \text { E desencarnando } & \text { Guardas noturnos, casais } \\ \text { Lá no Brejo da Cruz } & \text { São passageiros } \\ \text { Eletrizados } & \text { Bombeiros e babás } \\ \text { Cruzam os céus do Brasil } & \\ \text { Na rodoviária } & \text { Já nem se lembram } \\ \text { Assumem formas mil } & \text { Que existe um Brejo da Cruz } \\ & \text { Que eram crianças } \\ \text { Uns vendem fumo } & \text { E que comiam luz } \\ \text { Tem uns que viram Jesus } & \\ \text { Muito sanfoneiro } & \text { São faxineiros } \\ \text { Cego tocando blues } & \text { Balançam nas construções } \\ & \text { São bilheteiras } \\ \text { Uns têm saudade } & \text { Baleiros e garçons } \\ \text { E dançam maracatus } & \\ \text { Uns atiram pedra } & \text { Já nem se lembram } \\ \text { Outros passeiam nus } & \text { Que existe um Brejo da Cruz } \\ & \text { Que eram crianças } \\ & \text { E que comiam luz }\end{array}$

As situações descritas nesse poema são facilmente reconhecíveis para qualquer pessoa que viva numa grande cidade brasileira: crianças sem ter o que comer, obrigadas a aceitar o destino que não escolheriam si se tivessem a chance de fazer a opção. Nós, que vivemos uma vida confortável, os vemos todos os dias e sabemos qual é o futuro que os espera, mas não nos damos nem ao trabalho de nos perguntar de onde eles vêm, para onde vão, do que precisam. E 
isso podemos perceber nesses versos: Mas há milhões desses seres / que se disfarçam tão bem / Que ninguém pergunta / De onde essa gente vem.

É notável a ironia do poeta ao se referir a essas crianças como seres. Ora, um cachorro, um gato, um passarinho são seres. Essas crianças que se alimentam de luz e assumem formas mil são pessoas. O termo impessoal e frio é escolhido justamente para mostrar o quanto a sociedade fecha os olhos diante da situação. Mais irônico ainda é dizer que ninguém pergunta de onde eles vêm porque se disfarçam muito bem. É claro que essa gente não se esconde, pelo contrário. Eles não têm onde se esconder, vivem nas ruas. Mas são tantos, que a situação já nem parece tão chocante para nós.

E o pior é que eles mesmos acabam se conformando com seu infortúnio: Já nem se lembram / Que existe um brejo da Cruz / Que eram crianças / E que comiam luz. Jardineiros, guardas noturnos, babás, faxineiros, baleiros, etc. Uma imensa lista de atividades que em geral não podem proporcionar uma vida de muito conforto para ninguém, mas já é melhor do que se alimentar de luz. Então, é melhor esquecer a dor do passado e viver a dor de hoje, que ainda é sofrida, mas não tanto. E de qualquer forma, melhor não vai ficar. É uma visão pessimista, mas muito realista.

Outro belo retrato da difícil vida na cidade está em $O$ meu guri:

Quando, seu moço, nasceu meu rebento Não era o momento dele rebentar Já foi nascendo com cara de fome E eu não tinha nem nome pra lhe dar Como fui levando, não sei lhe explicar Fui assim levando ele a me levar E na sua meninice ele um dia me disse Que chegava lá

Olha aí

Olha aí

Olha aí, ai o meu guri, olha aí

Olha aí, é o meu guri

E ele chega

Chega suado e veloz do batente

E traz sempre um presente pra me encabular

Tanta corrente de ouro, seu moço

Que haja pescoço pra enfiar

Me trouxe uma bolsa já com tudo dentro

Chave, caderneta, terço e patuá

Um lenço e uma penca de documentos

Pra finalmente eu me identificar, olha aí

Olha aí, ai o meu guri, olha aí

Olha aí, é o meu guri

E ele chega
Chega no morro com o carregamento Pulseira, cimento, relógio, pneu, gravador Rezo até ele chegar cá no alto Essa onda de assaltos tá um horror Eu consolo ele, ele me consola Boto ele no colo pra ele me ninar De repente acordo, olho pro lado E o danado já foi trabalhar, olha aí Olha aí, ai o meu guri, olha aí Olha aí, é o meu guri E ele chega

Chega estampado, manchete, retrato Com venda nos olhos, legenda e as iniciais Eu não entendo essa gente, seu moço Fazendo alvoroço demais O guri no mato, acho que tá rindo Acho que tá lindo de papo pro ar Desde o começo, eu não disse, seu moço Ele disse que chegava lá Olha aí, olha aí

Olha aí, ai o meu guri, olha aí Olha aí, é o meu guri 
O poeta dá voz a uma mãe, moradora de alguma favela num morro qualquer, que aparentemente acredita que seu filho é um trabalhador honesto e se deu muito bem na vida, já que volta todos os dias com presentes caros. À primeira vista a notamos um orgulho imenso da mãe pelo sucesso do filho: Olha aí, ai o meu guri, olha aí. Mas quando lemos a lista de dos presentes trazidos - corrente de ouro, uma bolsa já com tudo dentro, chave, uma penca de documentos nos perguntamos: será possível tanta ingenuidade? Será que uma mãe não percebe que seu filho está recorrendo a meios escusos para sustentar a mãe e a si mesmo? Ou será que ela prefere fingir que não vê?

O mais provável é que essa mãe opte por ignorar a natureza do "trabalho" do filho, já que até o momento nada de mal aconteceu a ele. Notamos que ela se preocupa com a integridade física do filho: Rezo até ele chegar cá no alto. E que ela sabe muito bem o que acontece lá embaixo: Essa onda de assaltos está um horror. E a seguir, um belo momento de ternura entre mãe e filho: Eu consolo ele, ele me consola / Boto ele no colo pra ele me ninar. Ou seja, a mãe cuida do filho e o filho cuida da mãe, cada uma à sua maneira. A mãe encara a atividade do filho como a única saída encontrada para se salvar da miséria. E é por isso que, mesmo quando vê a imagem do filho estampada no jornal, continua achando que o filho chegou lá. Não admite nem para si mesma que seu filho se tornou um bandido porque, para ela, ele só o é da porta de casa para fora.

Assim, encaixamos mais uma peça no quebra-cabeças que é a poesia urbana de Chico Buarque. A desigualdade social e suas conseqüências: crianças abandonadas que não têm o que comer, ignoradas por pessoas que julgam não ter responsabilidade alguma nesse problema; favelas habitadas por gente pobre, por mães cujos filhos decidem entrar para o mundo do crime para tentar sobreviver. São muitos os flagelos da vida urbana e muitos deles estão retratados na obra de Chico Buarque. Mas a cidade não é apenas lugar de malandragem e tristeza. Há também muita beleza, e Chico não a deixa de lado.

\section{Quinta parte}

Em 1998, Chico lança um álbum intitulado As Cidades, no qual encontra-se Carioca, uma composição urbaníssima, mas de uma leveza até então inédita. Trata-se de uma declaração de 
amor à cidade do Rio de Janeiro, mas um Rio de Janeiro diferente daquele que aparecia em suas canções anteriores:

Gostosa
Quentinha
Tapioca
O pregão abre o dia
Hoje tem baile funk
Tem samba no Flamengo
O reverendo
No palanque lendo
O Apocalipse
O homem da Gávea criou asas
Vadia
Gaivota
Sobrevoa a tardinha
E a neblina da ganja
O povaréu sonâmbulo

\author{
Ambulando \\ Que nem muamba \\ Nas ondas do mar \\ Cidade maravilhosa \\ És minha \\ O poente na espinha \\ Das tuas montanhas \\ Quase arromba a retina \\ De quem vê \\ De noite \\ Meninas \\ Peitinhos de pitomba \\ Vendendo por Copacabana \\ As suas bugigangas \\ Suas bugigangas
}

O que predomina em Carioca é uma atmosfera suave, de quem admira as belezas de uma cidade sem ignorar seus problemas, mas não deixando que eles ofusquem seu brilho. Há uma mistura de imagens que acabam transformando a cidade num mosaico: tapioca quentinha, o pregão, o baile funk, a gaivota sobrevoando o mar, o povaréu. São coisas tão diferentes, mas tão típicos do Rio de Janeiro que não a mistura não soa estranha nem para que não vive lá.

Cidade maravilhosa / És minha: o poeta se sente tão à vontade que chega a se sentir o dono da casa. A imagem do pôr do sol é forte e bela como poucas: O poente na espinha / Das tuas montanhas / Quase arromba a retina / De quem vê. E para terminar, uma demonstração de que as mazelas não são ignoradas: De noite / Meninas / Peitinhos de pitomba / Vendendo por Copacabana / As suas bugigangas. Porém, o poeta está apenas constatando a existência da prostituição. Não há nenhuma reflexão sobre os problemas da cidade.

Em 2006, no seu último lançamento, o álbum Carioca, nos deparamos com um novo olhar para o Rio de Janeiro, aquele que está para trás do Cristo Redentor, em Subúrbio:

\author{
Lá não tem brisa \\ Não tem verde-azuis \\ Não tem frescura nem atrevimento \\ Lá não figura no mapa \\ No avesso da montanha, é labirinto \\ É contra-senha, é cara a tapa \\ Fala, Penha \\ Fala, Irajá \\ Fala, Olaria \\ Fala, Acari, Vigário Geral \\ Fala, Piedade
}

\author{
Casas sem cor \\ Ruas de pó, cidade \\ Que não se pinta \\ Que é sem vaidade \\ Vai, faz ouvir os acordes do choro-canção \\ Traz as cabrochas e a roda de samba \\ Dança teu funk, o rock, forró, pagode, reggae \\ Teu hip-hop \\ Fala na língua do rap \\ Desbanca a outra
}




$\begin{array}{ll}\text { A tal que abusa } & \text { Fala no pé } \\ \begin{array}{l}\text { De ser tão maravilhosa } \\ \text { Lá não tem moças douradas } \\ \text { Expostas, andam nus } \\ \text { Pelas quebradas teus exus }\end{array} & \text { Ná uma idéia } \\ \text { Não tem turistas } & \text { Lá não tem claro-escuro } \\ \text { Não sai foto nas revistas } & \text { A luz é dura } \\ \text { Lá tem Jesus } & \text { A chapa é quente } \\ \text { E está de costas } & \text { Que futuro tem } \\ \text { Fala, Maré } & \text { Aquela gente toda } \\ \text { Fala, Madureira } & \text { Perdido em ti } \\ \text { Fala, Pavuna } & \text { Eu ando em roda } \\ \text { Fala, Inhaúma } & \text { É pau, é pedra } \\ \text { Cordovil, Pilares } & \text { É fim de linha } \\ \text { Espalha a tua voz } & \text { É lenha, é fogo, é foda } \\ \text { Nos arredores } & \\ \text { Carrega a tua cruz } & \text { Fala, Penha } \\ \text { E os teus tambores } & \text { Fala, Irajá } \\ & \text { Fala, Encantado, Bangu } \\ \text { Vai, faz ouvir os acordes do choro-canção } & \text { Fala, Realengo... } \\ \text { Traz as cabrochas e a roda de samba } & \text { Fala, Maré } \\ \text { Dança teu funk, o rock, forró, pagode } & \text { Fala, Madureira } \\ \text { Teu hip-hop } & \text { Fala, Meriti, Nova Iguaçu } \\ \text { Fala na língua do rap } & \text { Fala, Paciência... } \\ & \end{array}$

Depois da exaltação, Chico parece fazer questão de reconhecer que o Rio não é apenas o que figura nos cartões-postais. Novamente, não temos reflexões profundas no sentido de revelar um grave problema para o resto da sociedade. Tampouco se trata de uma visão alienada e alheia à marginalização. Aqui o poeta percebe que lá no morro, no avesso da montanha, também há beleza, também há elementos que merecem ser cantados em sua poesia. Afinal, lá não figura no mapa, mas o poeta sabe da sua importância: Vai, faz ouvir os acordes do choro-canção / Traz as cabrochas e a roda de samba. O samba nasceu no morro, foi com o samba que Chico Buarque descobriu sua vocação para a música.

O mesmo poeta que canta Cidade maravilhosa / És minha, agora canta Desbanca a outra / A tal que abusa / De ser tão maravilhosa. Antes a luz do poente Quase arromba a retina / de quem vế; agora Lá não tem claro-escuro / A luz é dura. Um contraste, mas não uma contradição. Chico está mostrando que existem dois lados de uma mesma moeda. Se antes deixou falar a Cidade Maravilhosa, agora ele quer dar voz ao subúrbio, que, bem ou mal, é parte integrante da cidade: Fala, Penha / Fala, Irajá / Faça, Encantado, Bangu / Fala, Realengo...

Ou seja, depois de perceber e cantar aspectos específicos da vida urbana, o poeta passa a lançar um olhar mais amplo sobre a cidade, chegando a uma visão de conjunto própria de quem já tem maturidade suficiente para perceber que estamos todos no mesmo barco. A urbanização já 
é não mais um processo, é um fato concretizado do qual não podemos fugir. E os problemas que vieram com ela atingem e dizem respeito a todos nós, ainda que de formas diversas. Mas, por outro lado, não podemos deixar que eles nos impeçam de apreciar a beleza que a cidade pode nos proporcionar.

\section{Sexta parte}

Como vimos, Chico Buarque esteve preocupado com a questão social desde o início de sua produção artística. O comentário de Eric Nepomuceno, citado em artigo de Yudith Rosenbaum na revista Leia, de novembro de 1989, é bastante revelador: "Chico foi de uma geração que conheceu três Brasis: o viável, o derrotado e o esvaziado". O que me leva, inevitavelmente, a pensar nos três tipos de consciência do atraso classificados por Antonio Candido em Literatura e Subdesenvolvimento: amena, catastrófica e dilacerada.

O Chico dos anos 1960, que estréia com A Banda e Pedro Pedreiro, percebe que o avanço industrial está cada vez mais consolidado no país, mas isso não é garantia de qualidade de vida para todos os cidadãos brasileiros. Por outro lado, a esperança de que tal situação seja passageira é notável. A Banda que passa e resgata toda uma cidade da sua tristeza individualizada, ainda que por um curto instante, e a constante repetição do verbo esperando em Pedro Pedreiro são exemplos claros de que, apesar da dificuldade, ainda se acredita que há luz no fim do túnel. Assim, poderíamos relacionar esse momento à consciência amena do atraso, típica de quem ainda só conhece o Brasil viável.

Entretanto, quando chega à década de 1970, no auge da ditadura militar, o poeta já não é capaz de demonstrar o mesmo otimismo. O Brasil deste momento já não é mais viável. É um Brasil derrotado que podemos ler nas linhas de Construção. "Aquela esperança de tudo se ajeitar, pode esquecer...", dizia o poeta em Trocando em miúdos. O contexto era outro, mas o verso combina perfeitamente com essa nova perspectiva. O Pedro Pedreiro que esperava, esperava, esperava, morreu na contra-mão atrapalhando o tráfego. Ou seja, a consciência catastrófica do atraso nos mostra que não há mais lugar para a esperança.

Até mesmo o malandro carioca, que conseguia se safar de qualquer adversidade usando apenas a sua esperteza, agora tem mulher e filho e tralha e tal, e precisa trabalhar para sustentálos. Um outro tipo de malandro tomou seu posto agora: o malandro com gravata e capital, que 
nunca se dá mal. Assim, Chico reconhece a responsabilidade dos maus políticos sobre a situação em que o país se encontra. É um país esvaziado de valores éticos e morais; esvaziado de humanidade. E isso está bem claro em Brejo da Cruz e O Meu guri. São milhões de seres passando fome, se alimentando de luz, ou recorrendo à criminalidade para sobreviver. Mas a cidade não pára. É preciso seguir adiante, sem olha para trás ou para os lados. Porém, aos olhos do poeta esse problema não foge. E sua consciência, agora dilacerada, é revelada de maneira que nos força a fazer uma pausa, por mais breve que seja, e refletir sobre os rumos que a nossa sociedade está tomando.

Da década de 1990 em diante a perspectiva é completamente diferente. O que temos a partir de então é um poeta que assume claramente o Rio de Janeiro como a sua cidade. Num primeiro momento, é a Cidade Maravilhosa, aquela que é abraçada pelo Cristo Redentor. Mas depois, ele lança um olhar para o Rio que ficou para trás do Cristo. Maria Rita Kehl diz tudo na seguinte passagem:

Assim, depois de assumir-se como cidadão de um Rio de Janeiro invisível para a zonal sul, Chico abre o CD Carioca, de 2006, com a belíssima Subúrbio, a um só tempo continuação e ruptura em relação a tudo o que compôs até o momento tendo por tema as cidades. A canção Carioca foi uma aquarela maravilhada do Rio de Janeiro cujo mapa se estendia da Gávea até, no máximo, a Central do Brasil. Um Rio que os é familiar. Não por acaso, Carioca abre-se com esta espantosa elegia à outra cidade, o imenso labirinto "no avesso da montanha" que não sai nas revistas nem figura no mapa. (KEHL, 2006, p. 77)

Desse modo, podemos dizer que o poeta se tranqüilizou em relação à precariedade da vida nas grandes cidades do Brasil. Se o que separa a parte abastada da parte pobre é apenas uma imensa estátua de pedra, então está claro que não há mais fronteiras. A realidade dos centros urbanos brasileiros é que todas as classes sociais acabaram se tornando interdependentes. O pobre depende do rico, o rico depende do pobre. E todos sofrem as consequiências do atraso: o rico é rico porque alguém é pobre; o pobre passa fome porque alguém come mais do que precisaria para viver; o rico é assaltado, seqüestrado porque tem mais do que o pobre; o pobre depende do rico para lhe dar trabalho; o rico depende do pobre para lhe prestar serviço; o pobre precisa dos políticos para tirá-lo da miséria; os políticos precisam do pobre para colocá-los no poder.

E assim, infinitamente. Uma classe não existe sem a outra. Enquanto houver desigualdade social, os problemas não acabarão. Mas, já que ninguém parece disposto a fazer qualquer esforço para mudar a situação, não há motivo para se desesperar, para gritar por socorro. O que nos resta é nos tranqüilizarmos para poder aproveitar o que a cidade, seja ela qual for, pode nos oferecer de bom; temos de aceitar o risco para poder viver melhor. Portanto, ousando pensar num novo tipo 
de consciência do atraso, arrisco dizer que o poeta apresenta agora uma consciência conformada, acostumada com os riscos que a vida urbana oferece. O Brasil, que continua esvaziado de valores, é agora esvaziado de fronteiras sociais também.

\section{Referências}

BUARQUE, Chico. Chico Buarque Letra e Música. São Paulo: Cia das Letras, 2004.

CANDIDO, Antonio. Dialética da Malandragem. In: O Discurso e a Cidade. Rio de Janeiro: Ouro Sobre Azul, 2004.

Literatura e Subdesenvolvimento. In: A educação pela noite e outros ensaios. São Paulo: Ática, 2000.

KEHL, Maria Rita. Derradeira Estação. In: Revista Bravo!, nº 109, setembro de 2006.

ROSENBAUM, Yudith. Que rei sou eu? In: Revista Leia, nº 133, novembro de 1980. 